\title{
Gastrointestinal helminths of intensively managed poultry in Kwara Central, Kwara State, Nigeria: Its diversity, prevalence, intensity, and risk factors
}

\author{
Shola David Ola-Fadunsin ${ }^{1}$, Patricia Isioma Uwabujo ${ }^{1}$, Idiat Modupe Sanda ${ }^{1}$, Isau Aremu Ganiyu ${ }^{1}$, \\ Karimat Hussain ${ }^{1}$, Musa Rabiu ${ }^{1}$, Nusirat Elelu² and Musbau Olayinka Alayande ${ }^{1,3}$
}

1. Department of Veterinary Parasitology and Entomology, Faculty of Veterinary Medicine, University of Ilorin, P.M.B. 1515 Ilorin, Kwara State, Nigeria; 2. Department of Veterinary Public Health and Preventive Medicine, Faculty of Veterinary Medicine, University of Ilorin, P.M.B. 1515 Ilorin, Kwara State, Nigeria; 3. Department of Veterinary Parasitology and Entomology, Faculty of Veterinary Medicine, Usmanu Danfodiyo University, P.M.B. 2346 Sokoto, Sokoto State, Nigeria.

Corresponding author: Shola David Ola-Fadunsin, e-mail: olashodam2@yahoo.com

Co-authors: PIU: uwabujoisioma@rocketmail.com, IMS: sandaidiat12@gmial.com, IAG: ganiyuisau@gmail.com, KH: hussain.k@unilorin.edu.ng, MR: rabiu.m@unilorin.edu.ng, NE: nusyelelu@yahoo.com, MOA: musolade2000@yahoo.com Received: 18-09-2018, Accepted: 01-02-2019, Published online: 14-03-2019

doi: 10.14202/vetworld.2019.389-396 How to cite this article: Ola-Fadunsin SD, Uwabujo PI, Sanda IM, Ganiyu IA, Hussain K, Rabiu M, Elelu N, Alayande MO (2019) Gastrointestinal helminths of intensively managed poultry in Kwara Central, Kwara State, Nigeria: Its diversity, prevalence, intensity, and risk factors, Veterinary World, 12(3): 389-396.

\begin{abstract}
Aim: Helminth infections inflict negatively on the production and well-being of animals including poultry. This study was carried out to determine the prevalence, species diversity, intensity, and risk factors associated with the gastrointestinal helminths of intensively raised poultry in Kwara Central senatorial district of Kwara State.
\end{abstract}

Materials and Methods: Fecal samples were collected from 502 poultry species from 15 farms. The samples were subjected to floatation and the formalin-ethyl acetate concentration techniques of examination. The intensity of infections was determined using McMaster counting technique.

Results: Seven helminth species were detected with Heterakis gallinarum (10.2\%) and Ascaridia galli (6.0\%) been the most prevalent, while Capillaria species was the least prevalent (0.8\%). Physiological status, bird type, production purpose, farm age (years), presence of other animals in the farm, flock size (birds), farm size (acres), housing type, farm type, frequency of anthelmintic use, distance to waste area (meters), level of biosecurity, and frequency of cleaning the pen were the risk factors significantly $(\mathrm{p}<0.05)$ associated with the presence of helminth infections.

Conclusion: This study shows that helminth infections are endemic in the study area, as $66.7 \%$ of the sampled farms were infected with one or more helminth species. Findings from this study provide information that will assist in improving the poultry sector in Kwara State, Nigeria in general, for better production and profitability.

Keywords: epidemiology, gastrointestinal helminths, Kwara State, Nigeria, poultry.

\section{Introduction}

Poultry are domesticated birds kept by man for the purpose of obtaining meat, eggs, sometimes feathers, and as a means of livelihood. They include birds such as chicken, duck, goose, and turkey [1]. It is one of the most important sources of protein and farm manure, for man and so their importance cannot be overemphasized [1,2]. Poultry production has increased constantly throughout the world over the past decades, and according to the Food and Agriculture Organization [3], around $75 \%$ of a total of 15 billion chickens is found in the developing countries [4]. In Nigeria, poultry is an important component of the livestock subsector

\footnotetext{
Copyright: Ola-Fadunsin, et al. Open Access. This article is distributed under the terms of the Creative Commons Attribution 4.0 International License (http://creativecommons.org/licenses/ by/4.0/), which permits unrestricted use, distribution, and reproduction in any medium, provided you give appropriate credit to the original author(s) and the source, provide a link to the Creative Commons license, and indicate if changes were made. The Creative Commons Public Domain Dedication waiver (http:// creativecommons.org/publicdomain/zero/1.0/) applies to the data made available in this article, unless otherwise stated.
}

with a total population of over 200 million [5,6]. This sector has developed to the level of commercial enterprise which provides employment, income, and animal protein for urban and rural dwellers as well as manure for crop production [6]. It is an important instrument for alleviating problems associated with poverty in Nigeria and other developing countries (in terms of food security and malnutrition) [6].

The diseases condition caused by helminth infections is known as helminthosis. This condition has been considered as an important problem of poultry in Nigeria and other parts of the world [7-9]. Helminth parasites have been incriminated as a major cause of ill-health and loss of productivity through decreased feed conversion ratio, reduced weight gain and weight loss in broilers, poor egg lay in layers, and mortalities. Helminthoses are also associated with catarrh, diarrhea, intestinal obstruction, loss of appetite, anemia, weakness, paralysis, and poor feathering in birds $[1,2,7,9,10]$. Helminth parasites of poultry are commonly divided into three main groups; nematodes, cestodes, and trematodes. Nematodes constitute the 
most important group of helminth parasites of poultry, both in number of species and the extent of damage they cause. Few numbers of cestodes and trematodes are known to parasitize poultry $[7,11,12]$. The prevalence and intensity of helminth infections may be influenced by several factors, such as climatic conditions (temperature and humidity) which may alter the population dynamics of the parasites, resulting in dramatic changes in the prevalence and intensity of helminthic infections [12]. Many insects that may act as vectors for helminths are also favored by high temperatures and to some extent humidity $[1,12]$.

To the best of our knowledge, there is no report on gastrointestinal helminths of poultry in this part of the country. This study is, therefore, carried out to determine the prevalence, species diversity, intensity, and risk factors associated with the gastrointestinal helminths of intensively raised poultry with the aim of providing information on this subject matter that will help in better profitability in the poultry sector in the state and country.

\section{Materials and Methods}

\section{Ethical approval}

All applicable international, national, and/or institutional guidelines for the collection of fecal samples from avian species were correctly followed.

\section{Informed consent}

Informed consent was obtained from all participants.

\section{Description of study location}

This study was conducted in Kwara Central senatorial district of Kwara State. Kwara Central lies almost in the middle of Nigeria, and it is one of the major linkages between the northern and southern part of the country. Kwara Central comprises four local government areas (Asa, Ilorin East, Ilorin South and Ilorin West). Kwara State is located between latitude $8^{\circ} 05 \mathrm{~N}$ and $10^{\circ} 15 \mathrm{~N}$ and longitude $2^{\circ} 73 \mathrm{E}$ and $6^{\circ} 13 \mathrm{E}$. It is located in the middle belt (North Central) within the forest-savanna region of Nigeria (Figure-1). The state is bordered in the west by Benin Republic, in the east by Kogi State, and the south by Oyo, Osun, and Ekiti States. Kwara State population is about 3 million people, and it covers a total area of $34,500 \mathrm{~km}^{2} \mathrm{com}-$ prising rainforest in the south and wooded savannah in the larger part of the state. It has 16 local government areas. The state has two seasons, the dry and wet season, with heavier rainfall in September and October. The state has a mean annual rainfall of between $112.8 \mathrm{~cm}$ and $146.9 \mathrm{~cm}$ and an average annual temperature ranging from $22.1^{\circ} \mathrm{C}$ to $33.3^{\circ} \mathrm{C}$. It records a mean relative humidity of $49.6 \%[5,13]$.

\section{Study design and sampling}

A total of 502 fecal samples were collected from 15 poultry farms located within Kwara Central (Figure-1), comprising layers, broilers, and mixed species farms. The farms were visited between December

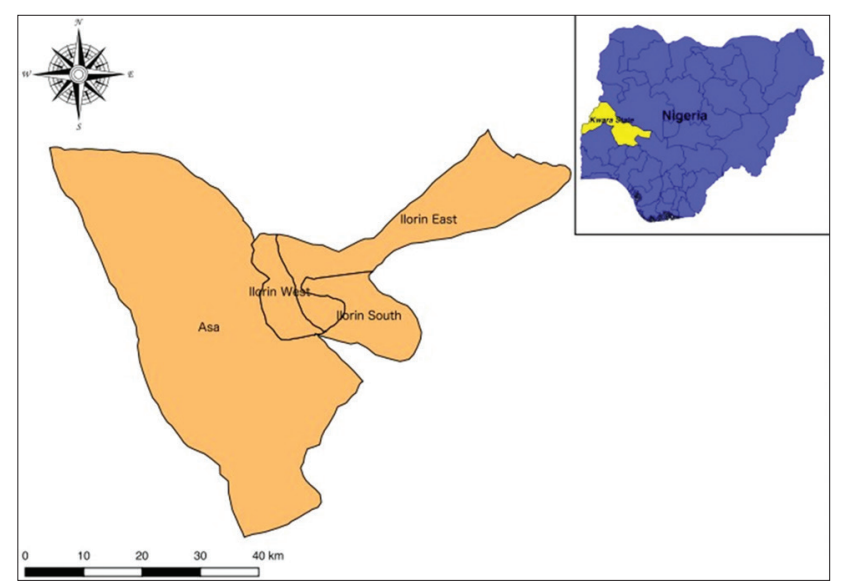

Figure-1: Map of Kwara Central (the study location). The insert map shows Kwara State within Nigeria (Designed using QGIS Version 2.6.1).

2017 and May 2018 following permission by the farm owners. Birds were monitored and individually freshly voided fecal samples were immediately collected from the ground and placed into well-labeled sterile sample bottles and put in a cool box. The samples were immediately transported to the Parasitology Laboratory of the Faculty of Veterinary Medicine, University of Ilorin, Nigeria, for further processing.

\section{Processing of fecal sample}

Fecal samples were processed using the simple floatation and the formalin-ethyl acetate concentration techniques. The floatation technique was carried out as described by Soulsby [14]. Briefly, $2 \mathrm{~g}$ of each fecal sample was mixed with quantity of saturated sodium chloride solution and filtered (using a sieve) into a glass test tube. Afterward, the mixture was filled to the brim (forming a meniscus) with the saturated sodium chloride solution, and a clean coverslip was gently placed on top of the test tube, thereby avoiding spillage. The coverslip was left for about $20 \mathrm{~min}$; afterward, the coverslip (having the harvested eggs) was placed on a clean glass slide and examined with the light microscope using the $10 \times$ and $40 \times$ objective lenses.

The formalin-ethyl acetate concentration technique was carried out as described by Cheesbrough [15]. Briefly, about $2 \mathrm{~g}$ of each feces was dissolved in $10 \%$ formalin and sieved into a plastic test tube to the $7 \mathrm{ml}$ mark and allowed to stand for a few minutes. $3 \mathrm{ml}$ of ethyl acetate was added. The tube was closed, vigorously shaken by hand for $1 \mathrm{~min}$, and centrifuged at $3000 \mathrm{rpm}$ for $5 \mathrm{~min}$. The debris plug was loosened, and the top three layers were discarded. Iodine stain preparation was made with the sediment, and the entire sediment was examined on a clean glass slide and covered with a clean coverslip. The covered slides were examined using $10 \times$ and $40 \times$ objective lenses.

\section{Fecal egg counts}

Samples that were positive for helminth eggs were subjected to the McMaster counting technique as described by Soulsby [14], with modifications to make use of a smaller volume of saturated sodium chloride 
solution. Briefly, $2 \mathrm{~g}$ of feces was properly dissolved in $12 \mathrm{ml}$ of saturated sodium chloride solutions (as against $60 \mathrm{ml}$ ). The solution was then filtered through a tea sieve into a beaker. The filtrate was pipetted into the two chambers of the McMaster slide. Afterward, it was allowed to stand for $30 \mathrm{~s}$. Finally, it was examined using the $10 \times$ objective lens. All the eggs seen within the ruled areas were counted. The eggs per gram (EPG) was estimated using the formulae below:

$$
\begin{aligned}
& \frac{\text { Number of eggs counted }}{\text { Weight of faeces }(2 \mathrm{~g})} \times \\
& \text { Total volume of Salt } \\
& \frac{\text { solution used }(12 \mathrm{ml})}{2(0.15 \mathrm{ml})}=20 \times(\mathrm{epg}) .
\end{aligned}
$$

\section{Identification of helminth eggs}

The eggs from the processing methods described above were identified using the helminthological keys as described by Soulsby [14] and Taylor et al. [16].

\section{Determination of positivity}

Samples that were positive in one or both of the tests carried out were considered positive for the helminth(s) detected.

\section{Determination of prevalence (\%) and mean intensity (EPG)}

The total prevalence (\%) of each helminth species was calculated as the total number of poultry infected with each helminth detected divided by the total number of poultry sampled (502), while the farm-based prevalence (\%) was calculated as the total number of poultry infected with a particular helminth detected in each farm divided by the total number of poultry sampled in that farm. The mean intensity (EPG) was calculated by summing the total EPG from all infected birds having a particular helminth species in a farm divided by the number of birds infected with the particular helminth parasite in that farm.

\section{Questionnaire design and administration}

A well-structured, interviewer-administered questionnaire containing open-ended and closedended (dichotomous or multiple choices) questions was designed to obtain information on individual bird that sample was collected from, the poultry farm demography, environmental and management factors, and biosecurity. A respondent was someone who was actively involved in the daily activities of the farm and was not necessarily the farm owner.

\section{Statistical analysis}

The data were statistically analyzed using the "Microsoft Excel 2010 and SPSS-Version 22.0" (SPSS Inc., Chicago). Descriptive statistics were conducted to estimate the prevalence using percentages in tables. The univariate analysis (Chi-square) test and odds ratios (ORs) with 95\% confidence interval (CI) were used to determine the association between each risk factor and the presence and absence of helminth parasites. The ORs were calculated with respect to a reference category as indicated in the respective tables. $\mathrm{p}<0.05$ was considered statistically significant for all analyses.

\section{Results}

\section{Overall prevalence $(\%)$ of helminth parasites}

Seven different species of helminth (six nematodes and one cestode) were detected from our study. Of the 502 birds sampled, $10.2 \%(51 / 502 ; 95 \%$ $\mathrm{CI}=7.7-13.0)$ were infected with Heterakis gallinarum, while $0.4 \%(2 / 502 ; 95 \% \mathrm{CI}=0.1-1.3)$ were infected with Syngamus trachea. The prevalence of the other helminths ranged between $0.8 \%$ and $6.0 \%$ (Figure-2).

\section{Prevalence $(\%)$ of helminth parasites coinfection among poultry}

Of the sampled birds, $84(16.7 \%)$ were infected with one helminth or the other. 66 of them were infected with one helminth species representing

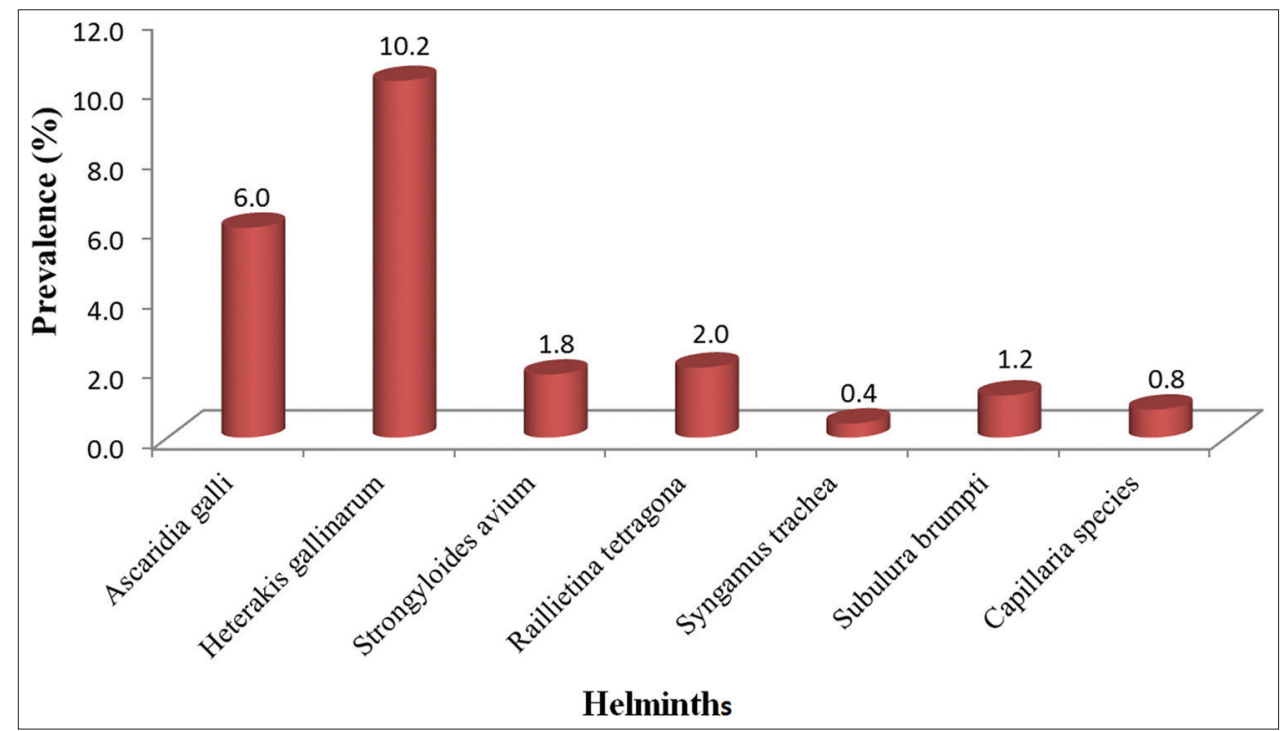

Figure-2: Prevalence (\%) of gastrointestinal helminths of intensively managed poultry in Kwara Central, Kwara State. 
Table-1: Prevalence (\%) of gastrointestinal helminths coinfection among intensively managed poultry in Kwara Central, Kwara State.

\begin{tabular}{|c|c|c|}
\hline $\begin{array}{l}\text { Gastrointestinal } \\
\text { helminth (s) }\end{array}$ & $\begin{array}{c}\text { Number } \\
\text { positive (\%) }\end{array}$ & $95 \% \mathrm{CI}$ \\
\hline One helminth infection & $66(13.2)$ & $10.4 ; 16.3$ \\
\hline Ascaridia galli & $18(3.6)$ & $2.2 ; 5.5$ \\
\hline Heterakis gallinarum & $33(6.6)$ & $4.6 ; 9.0$ \\
\hline Strongyloides avium & $5(1.0)$ & $0.4 ; 2.2$ \\
\hline Raillietina tetragona & $8(1.6)$ & $0.7 ; 3.0$ \\
\hline Subulura brumpti & $2(0.4)$ & $0.1 ; 1.3$ \\
\hline Two helminths infection & $12(2.4)$ & $1.3 ; 4.0$ \\
\hline $\begin{array}{l}\text { Ascaridia galli+Heterakis } \\
\text { gallinarum }\end{array}$ & $8(1.6)$ & $0.7 ; 3.0$ \\
\hline $\begin{array}{l}\text { Heterakis } \\
\text { gallinarum +Raillietina } \\
\text { tetragona }\end{array}$ & $2(0.4)$ & $0.1 ; 1.3$ \\
\hline $\begin{array}{l}\text { Heterakis } \\
\text { gallinarum +Strongyloides } \\
\text { avium }\end{array}$ & $2(0.4)$ & $0.1 ; 1.3$ \\
\hline Three helminths infection & $2(0.4)$ & $0.1 ; 1.3$ \\
\hline $\begin{array}{l}\text { Ascaridia galli+Heterakis } \\
\text { gallinarum+Strongyloides } \\
\text { avium }\end{array}$ & $2(0.4)$ & $0.1 ; 1.3$ \\
\hline Four helminths infection & $4(0.8)$ & $0.3 ; 1.9$ \\
\hline $\begin{array}{l}\text { Ascaridia galli+Heterakis } \\
\text { gallinarum +Subulura } \\
\text { brumpti+Capillaria species }\end{array}$ & $2(0.4)$ & $0.1 ; 1.3$ \\
\hline $\begin{array}{l}\text { Heterakis } \\
\text { gallinarum+Syngamus } \\
\text { trachea+Subulura } \\
\text { brumpti+Capillaria species }\end{array}$ & $2(0.4)$ & $0.1 ; 1.3$ \\
\hline
\end{tabular}

$\mathrm{CI}=$ Confidence interval

$13.2 \%(95 \% \mathrm{CI}=10.4-16.3)$. Of this category, $H$. gallinarum was the most prevalent $(33 / 502 ; 6.6 \% ; 95 \%$ $\mathrm{CI}=4.6-9.0)$, while Subulura brumpti was the least prevalent $(2 / 502 ; 0.4 \% ; 95 \% \mathrm{CI}=0.1-1.3)$. Ascaridia galli $+H$. gallinarum combination was the most prevalent in the two helminth parasites coinfection representing $1.6 \%$ of the sampled population. Two birds had three helminth parasites coinfection representing $0.4 \%(2 / 502 ; 95 \% \mathrm{CI}=0.1-1.3)$ of the sampled population. Four of the sampled birds were infected with four helminth parasites at the same time, with the infection been $A$. galli $+H$. gallinarum $+S$. brumpti + Capillaria species $(2 / 502 ; 0.4 \%)$ and $H$. gallinarum + S. trachea $+S$. brumpti + Capillaria species $(2 / 502$; $0.4 \%$ ) (Table-1).

\section{Prevalence (\%) of helminth parasites in the different poultry farms}

The farm prevalence of helminth infections is presented in Table-2. Of the 15 farms visited, five were free from helminth infections representing 33.3\%. One farm had birds that were infected with six of the seven helminth species detected, while other farms were infected with between one to three helminth species. H. gallinarum and A. galli had the widest spread, been detected in eight and seven farms, respectively, while the other helminth species were detected in one or two farms. In general, individual helminth prevalence within farms ranged between 6.3\% (A. galli in farm 3 ) and $56.7 \%$ (H. gallinarum in farm 8$)$.
Mean intensity of infections (EPG of feces) of helminth parasites in the different poultry farms

The highest mean intensity of infections was recorded in H. gallinarum (981.0) and closely followed by A. galli (751.4). Strongyloides avium, Raillietina tetragona, S. trachea, S. brumpti, and Capillaria species had a mean intensity of 360.0, 90.0, 60.0, 60.0, and 30.0, respectively. The individual mean intensity of infections within farms was highest in farm 4 with H. gallinarum recording $290.0( \pm 127.0)$ and lowest in farm 5 with Capillaria species recording $30.0( \pm 11.5)$ (Table-3).

\section{Risk factors associated with helminth parasitic infection}

The association between bird type and the occurrence of helminth infections was statistically significant $(\mathrm{p}<0.05)$. Layers $(18.5 \%)$ were 6.6 times more likely to be infected with helminth parasites compared to turkeys $(3.3 \%)$. Spent layers $(80.0 \%)$ were significantly $(\mathrm{p}<0.05)$ more prone to helminth infections compared to productive (16.1\%) and unproductive $(14.3 \%)$ birds. Poultry birds raised for the purpose of meat were twice less prone to the infection than those raised for egg purpose. Farms that are $<15$ years of the establishment are of higher risk of infection compared to farms older than 15 years. The presence of other animal types in the farm increases the chances of helminth infections $(\mathrm{OR}=2.0)$. The risk of helminth infections decreases with the increase in flock size, farm size, and distance to waste area. Birds raised in the deep litter had a lower risk (0.4) of infection compared to those raised in a battery cage. Birds raised in farms in the presence of other bird types were of higher risk (3.3) of infection compared to birds raised in farms with single bird species. Frequency of anthelmintic use, level of biosecurity, and frequency of cleaning the pen were other risk factors significantly associated $(p<0.05)$ with the occurrence of helminth infections (Table-4).

\section{Discussion}

Little or nothing is known about gastrointestinal helminth parasites of intensively managed poultry in Kwara Central as it pertains to its diversity, prevalence, intensity, and risk factors. The overall prevalence of $16.7 \%$ reported in this study is much lower than previous studies conducted in Nigeria: $42.5 \%$ [1], $81.0 \%$ [17], and 100.0\% [7] and outside Nigeria: $84.6 \%$ in Bangladesh [4] and 91.9\% in Iran [18]. The reason for the low prevalence recorded may be associated with the fact that the birds recruited for this study were intensively managed where they get better treatments in terms of biosecurity, hygiene, feeding, and appropriate preventive medical programs and general management. Higher helminth infections have been reported in extensively and semi-intensively raised birds compared to intensively raise domestic chickens [10].

The result of this study showed that seven species of helminths affect intensively managed poultry in the study area. Similar to our finding, Adang et al. [17] 
Table-2: The prevalence (\%) of gastrointestinal helminth parasites from the different poultry farms in Kwara Central, Kwara State.

\begin{tabular}{lccccccccc}
\hline Farms & $\mathbf{n}$ & \multicolumn{7}{c}{ Gastrointestinal helminths (number infected [prevalence \%]) } \\
\cline { 2 - 10 } & & $\begin{array}{c}\text { Ascaridia } \\
\text { galli }\end{array}$ & $\begin{array}{c}\text { Heterakis } \\
\text { gallinarum }\end{array}$ & $\begin{array}{c}\text { Strongyloides } \\
\text { avium }\end{array}$ & $\begin{array}{c}\text { Raillietina } \\
\text { tetragona }\end{array}$ & $\begin{array}{c}\text { Syngamus } \\
\text { trachea }\end{array}$ & $\begin{array}{c}\text { Subulura } \\
\text { brumpti }\end{array}$ & $\begin{array}{c}\text { Capillaria } \\
\text { species }\end{array}$ & $\begin{array}{c}\text { Number of } \\
\text { helminths }\end{array}$ \\
\hline 1 & 80 & $\mathrm{nf}$ & $\mathrm{nf}$ & $\mathrm{nf}$ & $\mathrm{nf}$ & $\mathrm{nf}$ & $\mathrm{nf}$ & $\mathrm{nf}$ & $\mathrm{nf}$ \\
2 & 30 & $4(13.3)$ & $\mathrm{nf}$ & $\mathrm{nf}$ & $\mathrm{nf}$ & $\mathrm{nf}$ & $\mathrm{nf}$ & $\mathrm{nf}$ & 1 \\
3 & 32 & $2(6.3)$ & $4(12.5)$ & $6(18.8)$ & $\mathrm{nf}$ & $\mathrm{nf}$ & $\mathrm{nf}$ & $\mathrm{nf}$ & 3 \\
4 & 30 & $\mathrm{nf}$ & $4(13.3)$ & $\mathrm{nf}$ & $\mathrm{nf}$ & $\mathrm{nf}$ & $\mathrm{nf}$ & $\mathrm{nf}$ & 1 \\
5 & 30 & $2(6.7)$ & $9(30.0)$ & $3(10.0)$ & $\mathrm{nf}$ & $2(6.7)$ & $6(20.0)$ & $4(13.3)$ & 6 \\
6 & 30 & $3(10.0)$ & $5(16.7)$ & $\mathrm{nf}$ & $\mathrm{nf}$ & $\mathrm{nf}$ & $\mathrm{nf}$ & $\mathrm{nf}$ & 2 \\
7 & 30 & $2(6.7)$ & $3(10.0)$ & $\mathrm{nf}$ & $5(16.7)$ & $\mathrm{nf}$ & $\mathrm{nf}$ & $\mathrm{nf}$ & 3 \\
8 & 30 & $13(43.3)$ & $17(56.7)$ & $\mathrm{nf}$ & $\mathrm{nf}$ & $\mathrm{nf}$ & $\mathrm{nf}$ & $\mathrm{nf}$ & 2 \\
9 & 33 & $\mathrm{nf}$ & $\mathrm{nf}$ & $\mathrm{nf}$ & $\mathrm{nf}$ & $\mathrm{nf}$ & $\mathrm{nf}$ & $\mathrm{nf}$ & $\mathrm{nf}$ \\
10 & 30 & $\mathrm{nf}$ & $\mathrm{nf}$ & $\mathrm{nf}$ & $\mathrm{nf}$ & $\mathrm{nf}$ & $\mathrm{nf}$ & $\mathrm{nf}$ & $\mathrm{nf}$ \\
11 & 30 & $4(13.3)$ & $\mathrm{nf}$ & $\mathrm{nf}$ & $\mathrm{nf}$ & $\mathrm{nf}$ & $\mathrm{nf}$ & $\mathrm{nf}$ & 1 \\
12 & 27 & $\mathrm{nf}$ & $\mathrm{nf}$ & $\mathrm{nf}$ & $\mathrm{nf}$ & $\mathrm{nf}$ & $\mathrm{nf}$ & $\mathrm{nf}$ & $\mathrm{nf}$ \\
13 & 30 & $\mathrm{nf}$ & $\mathrm{nf}$ & $\mathrm{nf}$ & $\mathrm{nf}$ & $\mathrm{nf}$ & $\mathrm{nf}$ & $\mathrm{nf}$ & $\mathrm{nf}$ \\
14 & 30 & $\mathrm{nf}$ & $5(16.7)$ & $\mathrm{nf}$ & $5(16.7)$ & $\mathrm{nf}$ & $\mathrm{nf}$ & $\mathrm{nf}$ & 2 \\
15 & 30 & $\mathrm{nf}$ & $4(13.3)$ & $\mathrm{nf}$ & $\mathrm{nf}$ & $\mathrm{nf}$ & $\mathrm{nf}$ & $\mathrm{nf}$ & 1 \\
\hline
\end{tabular}

$\mathrm{nf}=$ Not found

Table-3: The mean $( \pm S D$ ) intensity of gastrointestinal helminths (EPG of feces) of intensively managed poultry in individual farms in Kwara Central, Kwara State.

\begin{tabular}{|c|c|c|c|c|c|c|c|c|}
\hline \multirow[t]{2}{*}{ Farms } & \multicolumn{7}{|c|}{ Gastrointestinal helminths (mean $[ \pm S D]$ intensity of infections [EPG]) } & \multirow[t]{2}{*}{ Total } \\
\hline & Ascaridia galli & $\begin{array}{c}\text { Heterakis } \\
\text { gallinarum }\end{array}$ & $\begin{array}{c}\text { Strongyloides } \\
\text { avium }\end{array}$ & $\begin{array}{l}\text { Raillietina } \\
\text { tetragona }\end{array}$ & $\begin{array}{c}\text { Syngamus } \\
\text { trachea }\end{array}$ & $\begin{array}{l}\text { Subulura } \\
\text { brumpti }\end{array}$ & $\begin{array}{l}\text { Capillaria } \\
\text { species }\end{array}$ & \\
\hline 1 & $\mathrm{nf}$ & $\mathrm{nf}$ & $\mathrm{nf}$ & $\mathrm{nf}$ & $\mathrm{nf}$ & $\mathrm{nf}$ & $\mathrm{nf}$ & nf \\
\hline 2 & $160.0(8.2)$ & nf & $\mathrm{nf}$ & $\mathrm{nf}$ & $\mathrm{nf}$ & $\mathrm{nf}$ & $\mathrm{nf}$ & 160.0 \\
\hline 3 & $100.0(14.14)$ & $160.0(23.1)$ & $180.0(99.6)$ & $\mathrm{nf}$ & $\mathrm{nf}$ & $\mathrm{nf}$ & $\mathrm{nf}$ & 440.0 \\
\hline 4 & nf & $290.0(127.0)$ & $\mathrm{nf}$ & $\mathrm{nf}$ & $\mathrm{nf}$ & $\mathrm{nf}$ & $\mathrm{nf}$ & 290.0 \\
\hline 5 & $160.0(23.1)$ & $96.0(63.1)$ & $180.0(28.3)$ & $\mathrm{nf}$ & $60.0(28.3)$ & $60.0(35.7)$ & $30.0(11.5)$ & 586.0 \\
\hline 6 & $70.0(11.5)$ & $80.0(46.2)$ & $\mathrm{nf}$ & $\mathrm{nf}$ & $\mathrm{nf}$ & $\mathrm{nf}$ & $\mathrm{nf}$ & 150.0 \\
\hline 7 & $60.0(14.1)$ & $70.0(11.5)$ & $\mathrm{nf}$ & $50.0(11.5)$ & $\mathrm{nf}$ & $\mathrm{nf}$ & $\mathrm{nf}$ & 180.0 \\
\hline 8 & $151.4(55.3)$ & $145.0(64.3)$ & $\mathrm{nf}$ & nf & $\mathrm{nf}$ & $\mathrm{nf}$ & $\mathrm{nf}$ & 296.4 \\
\hline 9 & nf & nf & $\mathrm{nf}$ & $\mathrm{nf}$ & $\mathrm{nf}$ & $\mathrm{nf}$ & $\mathrm{nf}$ & $\mathrm{nf}$ \\
\hline 10 & $\mathrm{nf}$ & $\mathrm{nf}$ & $\mathrm{nf}$ & $\mathrm{nf}$ & $\mathrm{nf}$ & $\mathrm{nf}$ & $\mathrm{nf}$ & $\mathrm{nf}$ \\
\hline 11 & $50.0(11.5)$ & $\mathrm{nf}$ & $\mathrm{nf}$ & $\mathrm{nf}$ & $\mathrm{nf}$ & $\mathrm{nf}$ & $\mathrm{nf}$ & 50.0 \\
\hline 12 & nf & $\mathrm{nf}$ & $\mathrm{nf}$ & $\mathrm{nf}$ & $\mathrm{nf}$ & $\mathrm{nf}$ & $\mathrm{nf}$ & $\mathrm{nf}$ \\
\hline 13 & $\mathrm{nf}$ & $\mathrm{nf}$ & $\mathrm{nf}$ & $\mathrm{nf}$ & $\mathrm{nf}$ & $\mathrm{nf}$ & $\mathrm{nf}$ & $\mathrm{nf}$ \\
\hline 14 & $\mathrm{nf}$ & $60.0(16.3)$ & $\mathrm{nf}$ & $40.0(17.9)$ & $\mathrm{nf}$ & $\mathrm{nf}$ & $\mathrm{nf}$ & 100.0 \\
\hline 15 & $\mathrm{nf}$ & $80.0(69.3)$ & $\mathrm{nf}$ & nf & $\mathrm{nf}$ & $\mathrm{nf}$ & $\mathrm{nf}$ & 80.0 \\
\hline Total & 751.4 & 981.0 & 360.0 & 90.0 & 60.0 & 60.0 & 30.0 & 2332.4 \\
\hline
\end{tabular}

$\mathrm{nf}=$ Not found, $\mathrm{SD}=$ Standard deviation, $\mathrm{EPG}=$ Eggs per gram

reported seven gastrointestinal helminth species in domestic chickens in Gombe State, Nigeria. Contrary to our finding, Yoriyo et al. [19] reported eight gastrointestinal helminth species among chickens in Bauchi State, six helminth species in Abuja [11], five species in Akure, Ondo State [10], and four species in Sokoto State [20]. Outside Nigeria, 16 helminth species have been reported among chickens in South Africa [8], eight helminth species in India [21], seven species in Trinidad [9], six species in Bangladesh [18], four species in Iran [22], and three helminth species in Poland [23]. The differences in the number of helminth species detected in this study vis-à-vis those of other studies could be attributed to environmental and climatic differences. Our finding shows that there are diverse species of gastrointestinal helminths affecting poultry in Kwara Central of Kwara State.
This study reported that $H$. gallinarum and $A$. galli were the predominant helminth species, with $S$. avium, R. tetragona, S. trachea, S. brumpti, and Capillaria species been of lesser prevalence. This is comparable with that recorded by other authors [7,10,24], who recorded $H$. gallinarum and $A$. galli as the most prevalent helminth species of poultry in their studies conducted in Nigeria and Iran [25], respectively. Low prevalence of $S$. avium, $R$. tetragona, S. trachea, $S$. brumpti, and Capillaria species has also been reported in Nigeria $[1,11,24,26]$. The high prevalence of $H$. gallinarum and A. galli may be associated with the peculiarity in their life cycle as the eggs of both helminths can remain viable in the soil for several months [16], whereby prolonging the contamination time in the environment as birds constantly pick up viable eggs from the droppings that contaminate the 
Table-4: Risk factors associated with helminth infections among intensively managed poultry in Kwara Central, Kwara State.

\begin{tabular}{|c|c|c|c|c|}
\hline Variables & Helminth+ve (\%) & Helminth -ve (\%) & OR $(95 \% \mathrm{CI})$ & p-value \\
\hline \multicolumn{5}{|l|}{ Age (weeks) } \\
\hline Chick $(0-8)$ & $1(3.85)$ & $25(96.15)$ & $0.19(0.01,1.07)$ & 0.06 \\
\hline Grower (>8-16) & $13(19.70)$ & $53(80.30)$ & $1.19(0.60,2.27)$ & 0.59 \\
\hline Adult $(>16)$ a & $70(17.07)$ & $340(82.93)$ & 1.00 & \\
\hline \multicolumn{5}{|l|}{ Sex } \\
\hline Male & $4(7.84)$ & $47(92.16)$ & $0.40(0.12,1.05)$ & 0.06 \\
\hline Female ${ }^{a}$ & $80(17.74)$ & $371(82.26)$ & 1.00 & \\
\hline \multicolumn{5}{|l|}{ Bird type } \\
\hline Layers & $74(18.50)$ & $326(81.50)$ & $6.6(1.2,13.6)$ & $0.02^{\mathrm{b}}$ \\
\hline Broilers & $9(12.50)$ & $63(87.50)$ & $4.1(0.63,9.53)$ & 0.17 \\
\hline Turkeya & $1(3.33)$ & $29(96.67)$ & 1.00 & \\
\hline \multicolumn{5}{|l|}{ Physiological status } \\
\hline Unproductive & $26(14.29)$ & $156(85.71)$ & $0.04(0.01,0.20)$ & $<0.01^{\mathrm{b}}$ \\
\hline Productive & $50(16.13)$ & $260(83.87)$ & $0.05(0.01,0.22)$ & $<0.01^{\text {b }}$ \\
\hline Spent layers ${ }^{a}$ & $8(80.00)$ & $2(20.00)$ & 1.00 & \\
\hline \multicolumn{5}{|l|}{ Production purpose } \\
\hline Meat & $10(9.80)$ & $92(90.20)$ & $0.48(0.23,0.94)$ & $0.03^{b}$ \\
\hline $\mathrm{Egg}^{\mathrm{a}}$ & $74(18.50)$ & $326(81.50)$ & 1.00 & \\
\hline \multicolumn{5}{|l|}{ Farm age (years) } \\
\hline$<5$ & $32(21.05)$ & $120(78.95)$ & $28.85(5.36,60.34)$ & $<0.01^{\mathrm{b}}$ \\
\hline$>5-10$ & $28(18.67)$ & $122(81.33)$ & $24.83(4.58,52.4)$ & $<0.01^{\mathrm{b}}$ \\
\hline$>10-15$ & $23(25.56)$ & $67(74.44)$ & $36.92(6.64,78.53)$ & $<0.01^{\mathrm{b}}$ \\
\hline$>15-20^{a}$ & $1(0.91)$ & 109 (99.09) & 1.00 & \\
\hline \multicolumn{5}{|c|}{ Presence of other animals in the farm } \\
\hline Yes & $68(19.32)$ & $284(80.68)$ & $2.00(1.14,3.68)$ & $0.02^{\mathrm{b}}$ \\
\hline $\mathrm{No}^{\mathrm{a}}$ & $16(10.67)$ & $134(89.33)$ & 1.00 & \\
\hline \multicolumn{5}{|l|}{ Flock size (birds) } \\
\hline$<1000$ & $68(22.67)$ & $232(77.33)$ & $24.23(4.64,49.87)$ & $<0.01^{\text {b }}$ \\
\hline $1000-2000$ & $15(13.56)$ & $103(86.44)$ & $11.99(2.08,25.98)$ & $<0.01^{\mathrm{b}}$ \\
\hline$>2000^{a}$ & $1(1.19)$ & $83(98.81)$ & 1.00 & \\
\hline \multicolumn{5}{|l|}{ Farm size (acres) } \\
\hline$<5$ & $79(23.80)$ & $253(76.20)$ & $24.58(4.72,50.50)$ & $<0.01^{\mathrm{b}}$ \\
\hline $5-10$ & $4(4.44)$ & $86(95.56)$ & $3.65(0.45,9.99)$ & 0.26 \\
\hline$>10^{\mathrm{a}}$ & $1(1.25)$ & $79(98.75)$ & 1.00 & \\
\hline \multicolumn{5}{|l|}{ Housing type } \\
\hline Deep litter & $8(8.33)$ & $88(91.67)$ & $0.40(0.17,0.82)$ & $0.01^{\mathrm{b}}$ \\
\hline Battery cage $\mathrm{e}^{\mathrm{a}}$ & $76(18.72)$ & $330(81.28)$ & 1.00 & \\
\hline \multicolumn{5}{|l|}{ Farm type } \\
\hline Multiple bird species & $68(22.52)$ & $234(77.48)$ & $3.34(1.90,6.11)$ & $<0.01^{\mathrm{b}}$ \\
\hline Single bird species ${ }^{a}$ & $16(8.00)$ & $184(92.00)$ & 1.00 & \\
\hline \multicolumn{5}{|c|}{ Frequency of anthelmintic use } \\
\hline Every 2 months & $22(32.35)$ & $46(67.65)$ & $4.41(1.70,12.82)$ & $<0.01^{\mathrm{b}}$ \\
\hline Every 3 months & $52(19.12)$ & $220(80.88)$ & $2.20(0.94,5.91)$ & 0.07 \\
\hline Occasionally & $4(4.00)$ & $96(96.00)$ & $0.39(0.09,1.49)$ & 0.17 \\
\hline No at alla & $6(9.68)$ & $56(90.32)$ & 1.00 & \\
\hline \multicolumn{5}{|c|}{ Distance to waste area (meters) } \\
\hline$<250$ & $11(17.74)$ & $51(82.26)$ & $5.74(0.91,13.09)$ & 0.07 \\
\hline $250-500$ & $72(17.48)$ & $340(82.52)$ & $5.71(1.05,11.99)$ & $0.04^{b}$ \\
\hline$>500^{a}$ & $1(3.57)$ & $27(96.43)$ & 1.00 & \\
\hline \multicolumn{5}{|l|}{ Level of biosecurity (\%) } \\
\hline $0-25$ & $64(19.39)$ & $266(80.61)$ & $1.83(1.08,3.20)$ & $0.03^{b}$ \\
\hline $25-50^{a}$ & $20(11.63)$ & $152(88.37)$ & 1.00 & \\
\hline \multicolumn{5}{|c|}{ Frequency of cleaning the pen } \\
\hline Twice a week & $35(13.16)$ & $231(86.84)$ & $8.30(1.54,17.41)$ & $0.01^{b}$ \\
\hline Weekly & $48(26.67)$ & $132(73.33)$ & $19.86(3.70,41.47)$ & $<0.01^{\mathrm{b}}$ \\
\hline Occasionally ${ }^{a}$ & $1(1.79)$ & $55(98.21)$ & 1.00 & \\
\hline
\end{tabular}

aReference category. bSignificant. OR=Odds ratio, $\mathrm{CI}=$ Confidence interval

environment as they feed, and this also predisposes them to high prevalence and heavy parasite burden.

The helminths coinfection observed in this study is a common phenomenon in most poultry species $[9,17,27]$. This may be associated with the fact that some helminth infections require intermediate/paratenic host (e.g., earthworm) which can harbor and transmit more than one helminth species at a time [16].

The presence of helminth parasites in $66.7 \%$ of the visited farms shows that helminth infections are endemic among farms in the study area. Helminth has been known to cause reduced weight gain and weight loss in broilers, poor egg lay in layers, and 
mortalities [2,10], thereby resulting in production loss. The widespread of $H$. gallinarum and $A$. galli among farms confirms that these helminth species are the most endemic in the area and most parts of Nigeria as documented by previous researchers [1,11].

The mean intensity of infections showed not to be alarming as no helminth count was above 300 EPG. This low count may be attributed to the management system (intensive) in which the birds were raised. Nevertheless, this does not translate to optimum production in poultry as low intensity of helminth infections may also cause problems in a flock.

Higher prevalence of helminth infections was recorded in layers and broilers compared to turkey. This may not be readily explained, although prevalence of $68.3 \%$ has been reported in turkeys [26] compared to $88.4 \%$ in layers [10] with both works done in Nigeria. Spent layers had a higher prevalence of helminth infections compared to unproductive and productive birds. A study conducted in Germany reported that free-range chickens at the end of the laying period (spent layers) had greater intensity and prevalence of infection with $A$. galli and $H$. gallinarum compared to hens kept in closed poultry houses (in preparation for production or during production) [28]. This finding may be attributed to the fact that spent layers are not given much care in terms of medications and biosecurity as these birds are merely kept to be sold for meat. Moreover, one cannot rule out the effect of immunosuppression associated with aging which may also be a reason. Birds raised for the purpose of meat production had a lower prevalence of helminth infections compared to birds raised for egg production. Similarly, Afolabi et al. [10] reported a significantly lower prevalence of helminth infections in broilers compared to layers in their study carried out in Nigeria.

Birds raised in farms where other animals are present showed to be more prone to helminth infections compared to those raised in farms without other animal species. This is expected as other animals may serve as a vehicle in the transfer of viable helminth eggs into the farm $[10,16]$. Furthermore, the biosecurity in poultry farms where other animals are present (e.g., dogs) will be seriously compromised. Contrary to the expected outcome, birds raised in the deep litter had a lower prevalence of helminth infections compared to those raised in a battery cage. Bachaya et al. [29] and Teni et al. [30] reported that birds raised on deep litter were more infected with helminths than those raised in a battery cage. The frequent use of anthelminthic drugs by farms that raise their birds on deep litter may be the reason behind the contrary report between our study and other previous studies. The higher risk of infection seen in birds raised in the presence of other avian species may be associated with cross infections between different bird species.

Interestingly, birds that are occasionally treated with anthelmintics had the lowest prevalence of helminth infections while those that are treated every 2 months were most infected. This report may be attributed to anthelmintics resistance that is associated with its frequent use. Frequent use of anthelmintics increases the resistant population of nematodes [31,32].

Strunz et al. [33], Ikpeama et al. [34], and Taiwo et al. [35] have associated higher prevalence of helminth infections with proximity to waste area and level of sanitation and hygiene. These set of researchers reported that proximity, presence of waste, and poor level of hygiene and sanitation trigger the availability of helminth infections in man and livestock. In line with the report of these aforementioned researchers, we discovered an indirect relationship between the distance of to waste areas and level of biosecurity with the prevalence of helminth infections. Our findings may be attributed to the fact that helminths are known to require warmth, good humidity, and optimum temperature for eggs to hatch and develop to infective stage(s). Studies have shown that poor biosecurity provides favorable conditions for helminth infections in poultry $[36,37]$.

\section{Conclusion}

The findings of this study show that helminth infections are endemic in the study area, with $H$. gallinarum and $A$. galli been the most prevalent among the seven species detected. Two-third of the sampled farms was infected with one helminth parasite or the other. There was a low mean intensity of infections, and this will not rule out the economic effect, helminthosis cause on production. A number of factors were significantly associated with the positivity of helminth infections. This study will be essential for policy-making in other to improve poultry production in Kwara State and Nigeria as poultry occupy a pivotal aspect of the national livestock sector.

\section{Authors' Contributions}

SDO designed the study and was involved in sample collections and laboratory work. He also did the data analysis and drafted the manuscript. PIU was involved in the sampling and in laboratory work. IMS, IAG, KH, MR, and MOA were involved in the laboratory work. NE designed the map of the study location (figure-1) and was involved in sampling. All authors read and approved the final manuscript.

\section{Acknowledgments}

The authors would like to express their profound gratitude to the poultry farm owners for giving us attention and access to their birds. We are also grateful to the Department of Veterinary Parasitology and Entomology, Faculty of Veterinary Medicine, University of Ilorin, for making use of the laboratory equipment. The study was funded by the authors.

\section{Competing Interests}

The authors declare that they have no competing interests.

\section{Publisher's Note}

Veterinary World remains neutral with regard to jurisdictional claims in published map and institutional affiliation. 


\section{References}

1. Jegede, O.C., Asadu, I.A., Opara, M., Obeta, S.S. and Olayemi, D.O. (2015) Gastrointestinal parasitism in local and exotic breeds of chickens reared in Gwagwalada Guinea Savannah zone of Nigeria. Sokoto J. Vet. Sci., 13(3): 25-30.

2. Ngongeh, L.A., Chiejina, S.N. and Lawal, A.I. (2014) Prevalence of gastrointestinal helminth infections in slaughtered chickens reared in the Nsukka area of Enugu state, Nigeria. IOSR J. Agric. Vet. Sci., 7(11): 51-54.

3. FAO. (2004) FAOSTAT. Available from: http://www.fao. org. Last accessed on 18-08-2018.

4. Ferdushy, T., Hasan, M.T. and Kadir A.K.M. (2016) Crosssectional epidemiological investigation on the prevalence of gastrointestinal helminths in free-range chickens in Narsingdi district, Bangladesh. J. Parasit. Dis., 40(3): 818-822.

5. National Bureau of Statistics. (2016) Annual Abstract of Statistics. Federal Republic of Nigeria, Nigeria.

6. Ola-Fadunsin, S.D. (2017) Investigations on the occurrence and associated risk factors of avian coccidiosis in Osun state, Southwestern Nigeria. J. Parasitol. Res., 2017(8): 6.

7. Uhuo, A.C., Okafor, F.C., Odikamnoro, O.O., Onwe, C.S., Abarike, M.C. and Elom, J.N. (2013) Common gastrointestinal parasites of local chicken (Gallus domesticus) slaughtered in some selected eatery centers in Abakaliki, Ebonyi state: Implication for meat quality. Int. J. Dev. Sustain., 2(2): 1416-1422.

8. Mukaratirwa, S. and Khumaloa, M.P. (2010) Prevalence of helminth parasites in free-range chickens from selected rural communities in KwaZulu-Natal province of South Africa. J. S. Afr. Vet. Assoc., 81(2): 97-101.

9. Baboolal, V., Suratsingh, V., Gyan, L., Brown, G., Offiah, N.V., Adesiyun, A.A. and Basu, AK. (2012) The prevalence of intestinal helminths in broiler chickens in Trinidad. Vet. Arhiv, 82(6): 591-597.

10. Afolabi, O.J., Simon-Oke, I.A. and Olasunkanmi, A.O. (2016) Intestinal parasites of domestic chicken (Gallus gallus domesticus) in Akure, Nigeria. J. Biomed., 1(4): 1-4.

11. Matur, B.M., Dawam, N.N. and Malann, Y.D. (2010) Gastrointestinal helminth parasites of local and exotic chickens slaughtered in Gwagwalada, Abuja (FCT), Nigeria. N. Y. Sci. J., 3(5): 96-99.

12. Naphade, S.T. (2013) Studies on the prevalence of helminthic Infection in broiler poultry birds from Marathwada region, (MS) India. Sci. Res. Report., 3(2): 233-238.

13. Kwara State Government News. (2012) Kwara State Diary. Kwara State of Nigeria, Nigeria.

14. Soulsby, E.J.L. (1982) Helminths, Arthropods and Protozoa of Domestic Animals. $7^{\text {th }}$ ed. Bailliere Tindall Publishers, London. p787-792.

15. Cheesbrough, M. (2009) District Laboratory Practice in Tropical Countries. Cambridge University Press. United Kingdom. p196-198.

16. Taylor, M.A., Coop R.L. and Wall, R.L. (2007) Veterinary Parasitology. $3^{\text {rd }}$ ed. Blackwell Publishing Ltd, Oxford. p809.

17. Adang, K.L., Asher, R. and Abba, R. (2014) Gastrointestinal helminths of domestic chickens Gallus gallus domestica and ducks Anas platyrhynchos slaughtered at Gombe main market, Gombe state, Nigeria. Asian J. Poult. Sci., 8(2): 32-40.

18. Alam, M.N., Mostofa, M., Khan, M.A.H., Alim, M.A., Rahman, A.K.M. and Trisha, A.A. (2014) Prevalence of gastrointestinal helminth infections in indigenous chickens of selected areas of Barisal district, Bangladesh. Bangladesh J. Vet. Med., 12(2): 135-139.

19. Yoriyo, K.P., Adang, K.L., Fabiyi, J.P. and Adamu, S.U. (2008) Helminths parasites of local chickens in Bauchi state, Nigeria. Sci. World J., 3(2): 35-37.

20. Attah, D.D., Danladi, Y.K., Abdullahi, K. and Ibrahim, S.
(2013) A survey of gastrointestinal helminths of chickens and guinea fowls slaughtered at Sokoto, Nigeria. Equity $J$. Sci. Tech., 1(1): 1-5.

21. Kumar, S., Garg, R., Ram, H., Maurya, P.S. and Banerjee, P.S. (2015) Gastrointestinal parasitic infections in chickens of upper Gangetic plains of India with special reference to poultry coccidiosis. J. Parasit. Dis., 39(1): 22-26.

22. Badparva, E., Ezatpour, B., Azami, M. and Badparva, M. (2015) First report of birds infection by intestinal parasites in Khorramabad, West Iran. J. Parasit. Dis., 39(4): 720-724.

23. Tomza-Marciniak, A., Pilarczyk, B., Tobiańska, B. and Tarasewicz, N. (2014) Gastrointestinal parasites of freerange chickens. Ann. Parasitol., 60(4): 305-308.

24. Nnadi, P.A. and George, S.O. (2010) A cross-sectional survey on parasites of chickens in selected villages in the subhumid zones of South-Eastern Nigeria. J. Parasitol. Res., 2010(5): 6.

25. Ebrahimi, M., Asadpour, M., Khodaverdi, M. and Borji, H. (2014) Prevalence and distribution of gastrointestinal helminths in free-range chickens in Mashhad, Northeast of Iran. Sci. Parasitol., 15(1-4): 38-42.

26. Dauda, J., Lawal, J.R., Bello, A.M., Mustapha, M., Ndahi, J.J. and Biu A.A. (2016) Survey on the prevalence of gastrointestinal nematodes and associated risk factors in domestic Turkeys (Meleagris gallopavo) slaughtered in poultry markets in Bukuru Jos, Plateau state, Nigeria. Int. J. Innov. Agric. Biol. Res., 4(4): 27-36.

27. Junaidu, H.I., Luka, S.A. and Mijinyawa, A. (2014) Prevalence of gastrointestinal helminth parasites of the domestic fowl (Gallus gallus domesticus) slaughtered in Giwa market, Giwa local government, area, Kaduna state, Nigeria. J. Nat. Sci. Res., 19(4): 120-125.

28. Gawęcka, K. (2005) New views about maintenance of hen on playgrounds. Pol. Poult. J.11(3): 14-15.

29. Bachaya, H.A., Raza, M.A., Anjum, M.A., Khan, I.A., Aziz, A. Manzoor, Z. and Munawar, S.H. (2015) Prevalence of Ascaridia galli in white leghorn layers and FayoumiRhode Island red crossbred flock at government poultry farm Dina, Punjab, Pakistan. Trop. Biomed., 32(1): 11-16.

30. Teni, F., Adugna, S. and Keffale, M. (2017) Prevalence of Ascaridia galli in the intensive poultry production system in Eastern Hararghe zone, Eastern Ethiopia. Adv. Biol. Res., 11(3): 139-143.

31. Waller, P.J. (1987) Anthelmintic resistance and future for roundworm control. Vet. Parasitol., 15(2): 177-191.

32. Salam, S.T. (2015) Ascariasis in backyard chicken prevalence, pathology and control. Int. J. Recent Sci. Res., 6(4): 3361-3365.

33. Strunz, E.C., Addiss, D.G., Stocks, M.E., Ogden, S., Utzinger, J. and Freeman, M.C. (2014) Water, sanitation, hygiene, and soil-transmitted helminth infection: A systematic review and meta-analysis. PLoS Med., 11(3): e1001620.

34. Ikpeama, C.A., Obiajuru, I.O.C. and Ogomaka, A.I. (2016) The impact of refuse disposal dump sites on the spread of intestinal helminthiasis in Owerri metropolis, Imo state, South Eastern Nigeria. Int. J. Clin. Chem. Lab. Med., 2(2): 13-18.

35. Taiwo, O.T., Sam-Wobo, S.O. and Taiwo, A.M. (2016) Spatial distribution of helminth infections in Nigeria (20052015 ) and the need for attitudinal and behavioral changes in the water, sanitation and hygiene interventions. Ife J. Sci., 18(4): 913-930.

36. Permin, A., Bisgaard, M., Frandsen, F., Pearman, M., Nansen, P. and Kold. J. (1999) The prevalence of gastrointestinal helminths in different poultry production systems. Br. Poult. Sci., 40(4): 439-443.

37. Kaufmann, F. and Gauly, M. (2009) Prevalence and burden of helminths in local free range laying hens. Book of Abstracts of the $60^{\text {th }}$ Annual Meeting of the European Association for Animal Production. Wageningen Academic Publishers, Wageningen. p553. 